\title{
Diffusive transfer of oxygen from seamount basaltic crust into overlying sediments: An example from the Clarion-Clipperton Fracture \\ Zone
}

\author{
K. Mewes ${ }^{\mathrm{a}, *, 1}$, J.M. Mogollón ${ }^{\mathrm{a}, \mathrm{b}, \mathrm{c}, 1}$, , A. Picard ${ }^{\mathrm{c}, \mathrm{d}, \mathrm{e}}$, C. Rühlemann ${ }^{\mathrm{f}}$, A. Eisenhauer ${ }^{\mathrm{g}}$, \\ T. Kuhn ${ }^{\text {f }}$, W. Ziebis ${ }^{\text {h }}$, S. Kasten ${ }^{\text {a,c }}$ \\ a Alfred Wegener Institute Helmholtz Centre for Polar and Marine Research, Am Handelshafen 12, 27570 Bremerhaven, Germany \\ b Department of Geosciences - Geochemistry, P.O. Box 80.021, 3508TA Utrecht, Netherlands ${ }^{2}$ \\ ${ }^{\mathrm{c}}$ MARUM - Center for Marine Environmental Sciences, Leobener Str., 28359 Bremen, Germany \\ d Max Planck Institute for Marine Microbiology, Department of Biogeochemistry, Celsiusstrasse 10, 28359 Bremen, Germany

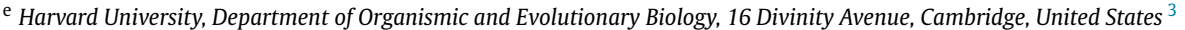 \\ ${ }^{\mathrm{f}}$ Bundesanstalt für Geowissenschaften und Rohstoffe (BGR), Stilleweg 2, 30655 Hannover, Germany \\ g GEOMAR Helmholtz Centre for Ocean Research Kiel, Wischhofstr. 1-3, 24148 Kiel, Germany \\ h Department of Biological Sciences, University of Southern California, 3616 Trousdale Parkway, Los Angeles, CA 90089-0371, United States
}

\section{A R T I C L E I N F O}

\section{Article history:}

Received 19 June 2015

Received in revised form 15 October 2015

Accepted 18 October 2015

Available online 11 November 2015

Editor: M. Frank

\section{Keywords:}

deep-sea sediments

eastern equatorial Pacific

redox zonation

basement-sediment interactions

seamounts

oxygen

\begin{abstract}
A B S T R A C T
The Clarion-Clipperton Fracture Zone (CCFZ) in the Pacific Ocean is characterized by organic carbonstarved sediments and meter-scale oxygen penetration into the sediment. Furthermore, numerous seamounts occur throughout its deep-sea plain, which may serve as conduits for low-temperature hydrothermal seawater circulation through the oceanic crust. Recent studies in deep-sea environments of the Pacific and Atlantic Oceans have suggested and presented evidence of dissolved constituent exchange between the seawater flowing in the basaltic crust and the pore water of the overlying sediments. Through high-resolution pore-water oxygen and nutrient measurements, we examined fluxes and geochemical interactions between the seamount basaltic basement and pore waters of the overlying sediments at three sites located on a radial transect from the foot of Teddy Bare, a small seamount in the CCFZ. At three sites, located 1000, 700 and $400 \mathrm{~m}$ away from the foot of the seamount, we found that oxygen concentrations initially decrease with sediment depth but start to increase at depths of 3 and $7 \mathrm{~m}$ toward the basaltic basement. Nitrate $\left(\mathrm{NO}_{3}^{-}\right)$concentrations mirror the oxygen concentration profiles, as they increase with sediment depth but decrease towards the basement. These profiles suggest an upward diffusion of oxygen from seawater circulating within the seamount crust into the overlying basal sediments and a downward diffusion of $\mathrm{NO}_{3}^{2-}$ from sediment pore water into the basaltic crust. At one site, we determined that the ${ }^{87} \mathrm{Sr} /{ }^{86} \mathrm{Sr}$ ratios of the bottom water and of the deep sediment near the basaltic crust are similar, further supporting diffusive exchange between basaltic crust fluids and sediment pore water.

Transport-reaction modeling performed at two of the study sites revealed that (1) the diffusive flux of oxygen from the basaltic basement outpaces the oxygen consumption through organic matter oxidation and nitrification in the basal sediments and (2) the nutrient exchange between the sediment and the underlying basaltic crust occurs at orders-of-magnitude lower rates than between the upper sediment and the overlying bottom water. These results further show that the diffusion of oxygen from the seamount basaltic basement into the overlying pore waters affects the preservation of organic compounds and helps to maintain a completely oxygenated sedimentary column at all 3 sites near the seamount.
\end{abstract}

(c) 2015 Elsevier B.V. All rights reserved.

\footnotetext{
* Corresponding author. Tel.: +49 471 48312236; fax: +49 47148311149. E-mail address: Konstantin.Mewes@gmx.de (K. Mewes).

1 These two authors have contributed equally to this manuscript.

2 Present address.

3 Present address.
}

\section{Introduction}

Deep-ocean, carbon-starved sediments account for about $70 \%$ of the global ocean floor (Berger, 1989; Bowles et al., 2014). In these environments, oxidized pore-water species are pervasively present in the sediment. Oxygen and nitrate have been detected 
at decimeter-scale sediment depths in the South Pacific Gyre (SPG: D'Hondt et al., 2009; Fischer et al., 2009; D'Hondt et al., 2015), the North Atlantic Gyre (NAG; Ziebis et al., 2012), and in the center of the North Pacific Gyre (NPG; Røy et al., 2012). Studies performed at sites located at the edge of the South and North Pacific Gyre and beneath the relatively productive equatorial regions of the Pacific Ocean have shown that the upper oxic zone of the sediments generally extends over a few meters (D'Hondt et al., 2009; Røy et al., 2012; Mewes et al., 2014). The prevalence of oxidized species in pore waters is generally a function of the influx of organic matter, the seawater oxygen concentrations, the sediment characteristics such as the burial rate and the porosity (e.g., Froelich et al., 1979; Berner, 1981). Recent investigations in sediments near crustal outcrops have demonstrated the existence of low-temperature hydrothermal seawater circulation through basaltic basement rock (Rudnicki et al., 2001; Wheat et al., 2002; Wheat and Fisher, 2008; Winslow and Fisher, 2015; Fisher et al., 2003). Evidence for fluid flow along the basaltic crust has been found in several locations worldwide. On the eastern flank of the Juan de Fuca Ridge three seamounts (Mama Bare, Papa Bare and Baby Bare), were identified as sites of hydrothermal discharge (Mottl et al., 1998; Wheat et al., 2004). On the basis of analysis of altered basaltic rocks, sediment pore fluids, and thermal gradients, these studies proposed that some of the water discharging at Baby Bare recharges at the Grizzly Bare outcrop $52 \mathrm{~km}$ away (Hutnak et al., 2001; Wheat et al., 2002). Wheat et al. (2002) concluded that generally cold oxygenated bottom seawater enters basaltic basement at Grizzly Bare, advects northeastward within basaltic basement parallel to the strike of a ridge, and vents naturally at the Baby and Mama Bares $\sim 50$ to $70 \mathrm{~km}$ to the north. Nevertheless, more recent investigations have shown that large seamounts have areas of both recharge and discharge (Winslow and Fisher, 2015).

Based on pore-water phosphate, nitrate, and manganese concentrations, Wheat and Fisher (2008) suggested that discharge also occurs at Dorado outcrop, a small basaltic edifice of the Cocos Plate. They proposed that seawater enters the basement at the Tengosed seamount and transits within the basaltic basement between Tengosed Seamount and the Dorado outcrop. During this transit, the fluid warms and reacts with the basaltic crust and becomes altered by both microbial and abiotic processes. Fisher and Wheat (2010) pointed out that the difference between pressures at the base of recharging and discharging fluid columns within the crust is the primary driving force moving fluids in and out of oceanic crust on ridge flanks. They argued that in areas of ridge-flank hydrothermal recharge the fluid pressure is greatest at the base of a cold column of crustal fluid, where the downward flow is sufficiently rapid so as to minimize heating during descent, and lower at the base of an upward flowing column of (warmer) discharging hydrothermal fluids.

This circulation of fluids in basaltic crusts may induce an upward oxygen diffusive flux from the crust into the overlying sediments thus bringing additional oxidizing power into the lower portions of the sediment (Ziebis et al., 2012). Oxygen pore-water profiles measured in the western flank of the Mid-Atlantic Ridge at the North Pond site of the Atlantic Ocean demonstrated that diffusive oxygen input from both overlying seawater and fluids flowing through the basaltic crust produced concave oxygen profiles in the sedimentary pore waters (Ziebis et al., 2012).

In the current study we present ex situ oxygen data, obtained by means of amperometric oxygen sensors, and pore-water data for three sites along a transect at the foot of a small seamount, named Teddy Bare, which is located in the northern part of the German license area "East" for manganese nodule exploration in the eastern Clarion-Clipperton Fracture Zone (CCFZ). We recovered three sediment cores in order to characterize geochemical processes throughout the sediment column and to elucidate the impact of basement-sediment interaction on (bio)geochemical processes in the overlying carbon-starved sediments. Furthermore, we conducted reaction-transport modeling, to determine (1) the diffusive fluxes of oxygen and phosphate from the basaltic basement into the sediment, (2) the diffusive flux of nitrate from the sediment into the basaltic basement, and (3) the rates of organic matter degradation in the sediments overlying the oceanic crust.

\section{Material \& methods}

Sediment material was retrieved during RV SONNE cruise SO205 in April/May 2010 (Rühlemann et al., 2010) and BIONOD cruise with RV L'ATALANTE in spring 2012 in the equatorial northeastern Pacific Ocean (Rühlemann et al., 2012). The study area is located in the German license area "East" (Fig. 1) within the Clarion-Clipperton Fracture Zone (CCFZ). The German license area "East" is authorized for manganese nodule exploration by the International Seabed Authority (ISA). The area is punctuated by hundreds of seamounts with diameters ranging from 3 to $30 \mathrm{~km}$ and varying heights above the surrounding seafloor of up to $2800 \mathrm{~m}$ (Rühlemann et al., 2011). Furthermore, the deep-sea plains of the CCFZ are interspersed with elongated NNE-SSW oriented horst and graben structures approximately $200 \mathrm{~km}$ long (Haxby and Weissel, 1986). Winterer and Sandwell (1987) showed that in the CCFZ these graben structures are actually manifested as basement volcanic ridges, seamount chains, or volcanic sills and flows. For this study sediment cores recovered from three sites along a transect at the foot of the $240 \mathrm{~m}$ high Teddy Bare seamount were investigated. Piston core (PC) BIO12-60PC (10.7 m long) was taken $1000 \mathrm{~m}$ away from the foot of the seamount, gravity core (GC) SO205-59GC $(6.3 \mathrm{~m})$ and multicorer core (MUC) SO205-65MUC $(0.28 \mathrm{~m})$ were collected about $700 \mathrm{~m}$ away from the foot of the seamount, and piston core BI012-53PC $(9.9 \mathrm{~m})$ was retrieved closest to the foot of the seamount at about $400 \mathrm{~m}$ distance (Fig. 1; Table 1). The sediment echosounder (Ixsea Echoes 3500 subbottom profiler, onboard RV L'Atalante) was used to determine the sediment thickness above the basaltic crust. This profile, and pieces of basalt found in the core catcher demonstrate that at site BI012-53PC, located closest to the seamount, the entire sediment column overlying the basaltic crust was recovered. Details about the bathymetry in the German license area "East" can be found in Rühlemann et al. (2011) and Rühlemann et al. (2012).

\subsection{Ex situ oxygen measurements}

Immediately after recovery, the GCs and PCs were cut into $1 \mathrm{~m}$ segments, transferred into the vessels cold room, and stored at $4{ }^{\circ} \mathrm{C}$. In order to allow temperature equilibration, oxygen measurements were performed at least $12 \mathrm{~h}$ after core recovery. Ex situ oxygen measurements were performed every $5 \mathrm{~cm}$ for the PCs and GCs. For the MUC from site SO205-59GC, oxygen measurements were performed in intervals of $1 \mathrm{~mm}$ across the sediment/water interface down to $6 \mathrm{~cm}$ sediment depth, continued by measurements at every $1 \mathrm{~cm}$ interval to $10 \mathrm{~cm}$, and in $2-\mathrm{cm}$ intervals to the end of the core. For the deeper measurements, holes with a diameter of $\sim 2 \mathrm{~mm}$ were drilled into the core liners. Oxygenmeasurements were performed following the procedure described by Ziebis et al. (2012). Oxygen concentrations in the sediments were determined using amperometric Clark-type oxygen sensors with an internal reference and equipped with a guard cathode (Revsbech, 1989), which produces measurements with an error of $\sim 5 \%$. Signals were amplified and transformed to $\mathrm{mV}$ by a picoammeter, digitalized by an analogue/digital converter (ADC 216, Unisense, Denmark) and recorded by a computer using the PROFIX and the SensorTrace PRO software (Unisense, Denmark). 


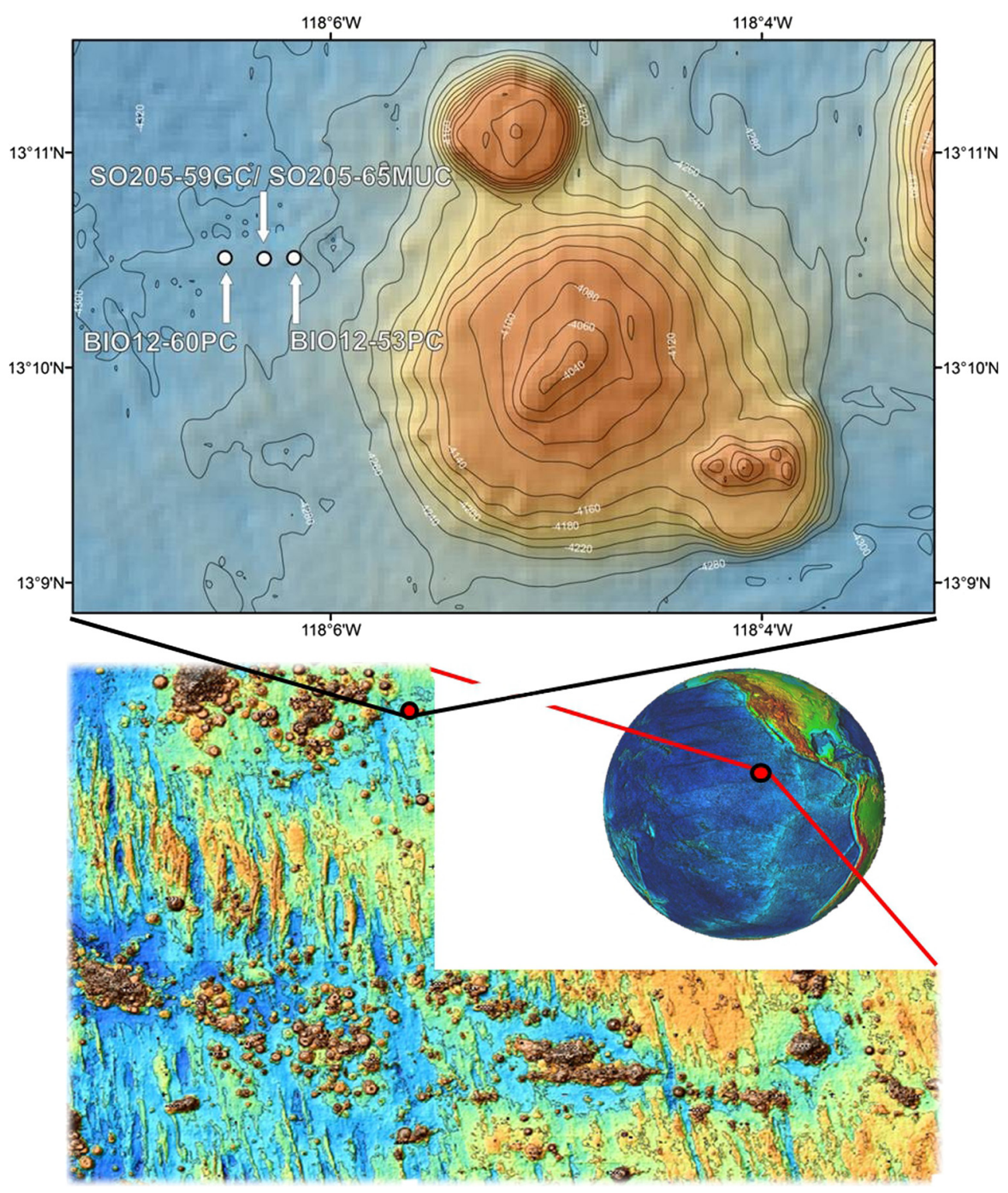

Fig. 1. Bathymetric map of the working area at the foot of the Teddy Bare seamount.

Table 1

Coordinates, water depths and core lengths of retrieved piston and gravity cores.

\begin{tabular}{|c|c|c|c|c|c|c|c|}
\hline Site & Core number & Device $^{a}$ & $\begin{array}{l}\text { Latitude } \\
{[\mathrm{N}]}\end{array}$ & $\begin{array}{l}\text { Longitude } \\
{[\mathrm{W}]}\end{array}$ & $\begin{array}{l}\text { Water depth } \\
{[\mathrm{m}]}\end{array}$ & $\begin{array}{l}\text { Core length } \\
{[\mathrm{m}]}\end{array}$ & $\begin{array}{l}\text { Distance to the seamount } \\
\text { [m] }\end{array}$ \\
\hline BIO12-60PC & BIO12-60PC & PC & $13^{\circ} 10.51$ & $118^{\circ} 06.49$ & 4287 & 10.7 & 1000 \\
\hline \multirow[t]{2}{*}{ SO205-59GC } & SO205-59GC & GC & $13^{\circ} 10.51$ & $118^{\circ} 06.31$ & 4283 & 6.3 & 700 \\
\hline & SO205-65MUC & MUC & $13^{\circ} 10.50$ & $118^{\circ} 06.30$ & 4283 & 0.28 & 700 \\
\hline BI012-53PC & BI012-53PC & PC & $13^{\circ} 10.51$ & $118^{\circ} 06.17$ & 4282 & 9.9 & 400 \\
\hline
\end{tabular}

a PC, piston core; GC, gravity core; MUC, multiple core.

\subsection{Pore-water and sediment sampling}

Before sampling, the 1-m long core segments of the GCs and PCs were split into two halves. The "working half" of the core was used for pore-water and sediment sampling at a spacing of $20 \mathrm{~cm}$. The other half of the core was archived. The MUC SO205-65MUC recovered from site SO205-59GC was sampled in steps of $1 \mathrm{~cm}$ within the uppermost $10 \mathrm{~cm}$ of the sediments and at $2-\mathrm{cm}$ intervals below. Pore water was retrieved by rhizons with an average pore diameter of $0.15 \mu \mathrm{m}$ (Rhizosphere Research Products, Wageningen) according to the procedure described by Seeberg-Elverfeldt et al. (2005) and Dickens et al. (2007).

\subsection{Pore-water and solid-phase analyses}

All analyses of pore-water samples retrieved during RV SONNE cruise SO205 were performed onboard. Nitrate was measured using a FIAlab 2600 system, based on the sulphanile- $\alpha$-naphthylamide method according to Grasshoff et al. (1999). The detection limit for nitrate was $1.6 \mathrm{nmol}^{-1}$. Phosphate was determined photometrically (Lange DR2800) using the molybdenum blue method (Grasshoff et al., 1999). Samples for nitrate and phosphate measurements were analyzed in triplicate with an analytical precision better than $5 \%$ and a reproducibility of $97 \%$. Aliquots of the original pore-water samples for stable $\mathrm{Sr}$ isotope measurements (site 
Table 2

Modeled species, with their respective top boundary (TB) and bottom boundary (BB) conditions. The reactions affecting each species are also listed.

\begin{tabular}{|c|c|c|c|c|c|c|c|c|}
\hline Species & Name & Species unit & $\begin{array}{l}\text { TB site } \\
\text { BIO12-53PC }\end{array}$ & $\begin{array}{l}\text { BB site } \\
\text { BI012-53PC }\end{array}$ & $\begin{array}{l}\text { TB site } \\
\text { SO205-59GC }\end{array}$ & $\begin{array}{l}\text { BB site } \\
\text { SO205-59GC }\end{array}$ & $\begin{array}{l}\text { Boundary condition } \\
\text { type }^{a} \text { : unit }\end{array}$ & Reaction rate \\
\hline TOC & total organic carbon & dry wt\% & 0.068 & $\mathrm{~N} / \mathrm{A}$ & 0.035 & $\mathrm{~N} / \mathrm{A}$ & $\mathrm{F}: \mathrm{mol} \mathrm{m}^{-2} \mathrm{y}^{-1}$ & $-R_{T O C}$ \\
\hline $\mathrm{O}_{2}$ & dissolved oxygen & $\mu \mathrm{M}$ & 160 & 80 & 160 & 100 & $\mathrm{C}: \mu \mathrm{M}$ & $-\varepsilon R_{T O C}-R_{\text {amox }}$ \\
\hline $\mathrm{NH}_{4}^{+}$ & ammonium & $\mu \mathrm{M}$ & 0.1 & 0.1 & 0.1 & 0.1 & $\mathrm{C}: \mu \mathrm{M}$ & $16 / 106 \varepsilon R_{T O C}$ \\
\hline $\mathrm{NO}_{3}-$ & nitrate & $\mu \mathrm{M}$ & 45 & 35 & 45 & 35 & $\mathrm{C}: \mu \mathrm{M}$ & $R_{\text {amox }}$ \\
\hline
\end{tabular}

a $\mathrm{F}=$ Fixed flux, $\mathrm{C}=$ Fixed concentration. $\varepsilon=\left(\frac{1}{100 \%}\right)\left(\frac{\mathrm{molC}}{12 \mathrm{gC}}\right)\left(\frac{2.6 \mathrm{~g}}{\mathrm{~cm}^{3} \mathrm{ds}}\right)\left(\frac{\left(1-\varphi_{i}\right) \mathrm{cm}^{3} \mathrm{ds}}{\varphi_{i} \mathrm{~cm}^{3} \mathrm{pw}}\right)\left(\frac{10^{3} \mathrm{~cm}^{3}}{\mathrm{~L}}\right)\left(\frac{10^{6} \mu \mathrm{mol}}{\mathrm{mol}}\right)$.

SO205-59GC) were transported from the ship under cooled conditions $\left(4^{\circ} \mathrm{C}\right)$ to the laboratory of the Alfred Wegener Institute Helmholtz Centre for Polar and Marine Research in Bremerhaven (AWI). Measurements were finally carried out at the GEOMAR Helmholtz Centre for Ocean Research Kiel mass spectrometer facilities in Kiel, Germany, using a TRITON mass spectrometer (Thermofisher) with an error of $\sim 5 \%$.

Pore-water samples retrieved during the BIONOD cruise were diluted 1:2 with demineralized water and stored frozen $\left(-20^{\circ} \mathrm{C}\right)$ until analysis in the home laboratory of the AWI. Nitrate and phosphate concentrations in pore-water of the BIONOD samples were determined using a QuAAtro (Seal Analytical; detection limit is $1.9 \mathrm{nM}$ for nitrate and $1.3 \mathrm{nM}$ for phosphate). Samples were analyzed in triplicate with an analytical precision better than $6 \%$ and a reproducibility of $96 \%$.

Solid-phase samples collected from cores retrieved during both cruises were transported under cooled conditions $\left(4^{\circ} \mathrm{C}\right)$ from the ship to the AWI. The sediment samples were freeze-dried and subsequently ground in an agate mortar. The total organic carbon (TOC) content of the homogenized bulk sediment was determined by combustion analysis with a CS 2000 Carbon-Sulfur Determinator.

\subsection{Geochemical modeling}

A one-dimensional reaction transport model (Boudreau, 1997; Mogollón et al., 2012) was used to track the fate of TOC, oxygen, and nitrate. The model couples reactions through a discretized reaction-transport equation (Eq. (1)):

$$
\begin{aligned}
\vartheta_{i} \frac{\partial C_{i, j}}{\partial t}= & \frac{\partial D_{i, j} \vartheta_{i}\left(\partial C_{i, j} / \partial z\right)}{\partial z}-\frac{\partial \omega_{i} \vartheta_{i} C_{i, j}}{\partial z} \\
& +\vartheta_{i} \sum R_{i}+\vartheta_{i} \alpha_{i}\left(C_{0, j}-C_{i, j}\right)
\end{aligned}
$$

where $t$ is time, $z$ is sediment depth, and $i, j$ represent subscripts depicting depth- and species-dependence respectively. $C$ is the species concentration (aqueous or solid species, Table 2); $D$ is the diffusive mixing coefficient (Eq. (6)); $\alpha$ is the bioirrigation coefficient (for aqueous species only, i.e. $\alpha=0$ for TOC); $\vartheta$ is the volume fraction for the aqueous (i.e. the porosity $\left.\varphi_{i}\right)$ or solid $\left(1-\varphi_{i}\right)$ phases; $\omega_{i}$ is the velocity of either the aqueous or the solid phase ( $v_{i}$ or $w_{i}$, respectively); $\sum R_{i}$ is the sum of the reactions affecting the given species $j$. In Eq. (1), the term on the left hand side represents the change in concentration with time assuming that volume fractions follow steady-state compaction. The first term of the right hand side of Eq. (1) represents diffusion, the second term represents advection, the third term represents the reactions, and the final term represents non-local sources/sinks (bioirrigation). Simulations were run until steady state was reached, that is, when all constituent profiles varied by less than $0.01 \%$ between years. The parameters used for the simulations are depicted in Table 3. The nomenclature is also fully stated in Supplementary Table 1.

Due to the high concentrations of oxygen present throughout the sediment column, denitrification was assumed to be inhibited, and thus the only pathway for organic matter degradation was assumed to be aerobic respiration (Eq. (2)), which was modeled using reactive continuum kinetics assuming a gamma function distribution of reactive types (Boudreau and Ruddick, 1991, $R_{T O C}$, Eq. (3)):

$$
\begin{aligned}
& \left(\mathrm{CH}_{2} \mathrm{O}\right)\left(\mathrm{NH}_{4}^{+}\right)_{\frac{16}{106}}+\mathrm{O}_{2} \rightarrow \mathrm{HCO}_{3}^{-}+\mathrm{H}^{+}+\frac{16}{106} \mathrm{NH}_{4}^{+} \\
& R_{T O C}=\frac{\sigma C_{T O C}^{1+1 / \sigma}}{a C_{T O C, 0}^{1 / \sigma}}
\end{aligned}
$$

where $a$ and $\sigma$ are free parameters that govern the reactivity of the organic matter pools. a represents the average age of the labile pools and controls the reaction constant, while $\sigma$ represents the distribution of refractive components and controls both the reaction constant and the order of the degradation reaction.

Net ammonium oxidation (Eq. (4)): was represented through a bimolecular rate law ( $R_{a m o x}$, Eq. (5)):

$$
\begin{aligned}
& \mathrm{NH}_{4}^{+}+2 \mathrm{O}_{2} \rightarrow \mathrm{NO}_{3}^{-}+2 \mathrm{H}^{+}+\mathrm{H}_{2} \mathrm{O} \\
& R_{\text {amox }}=k_{\text {amox }} \mathrm{C}_{\mathrm{NH}_{4}^{+}} \mathrm{C}_{\mathrm{O}_{2}}
\end{aligned}
$$

Biologically induced mixing was assumed to follow an inverse logistic regression with sediment depth, with a generalized mixing depth and mixing attenuation:

$D_{i, j}=\frac{D_{b, 0} \exp \left(\frac{z_{\text {mix }}-z}{z_{a t t}}\right)}{1+\exp \left(\frac{z_{\text {mix }}-z}{z_{\text {att }}}\right)}+\frac{D_{m, j}}{1-2 \ln \left(\varphi_{i}\right)}$

$\alpha_{i}=\frac{\alpha_{0} \exp \left(\frac{z_{\text {mix }}-z}{z_{a t t}}\right)}{1+\exp \left(\frac{z_{\text {mix }}-z}{z_{\text {att }}}\right)}$

Where $\alpha_{0}$ is the maximum bioirrigation coefficient (zero for solids and assumed constant for aqueous species), $D_{b, 0}$ is the maximum bioturbation coefficient (near the sediment-water interface), $z_{\text {mix }}$ is the depth to where $\alpha$ and $D_{b}$ become half the value of $\alpha_{0}$ and $D_{b, 0}$ and $z_{a t t}$ is the attenuation of the biogenically induced mixing with depth. $D_{m, j}$ is the temperature-corrected molecular diffusion coefficient following Boudreau (1997). The temperature was assumed to be constant at $1.9{ }^{\circ} \mathrm{C}$ (Rühlemann et al., 2012).

Porosity was assumed to decrease exponentially with depth to an asymptotic value (e.g. Berner, 1980).

$\varphi_{i}=\varphi_{\infty}+\left(\varphi_{0}-\varphi_{\infty}\right) \exp (-\beta z)$

where $\varphi_{\infty}$ is the porosity at compaction, $\varphi_{0}$ is the porosity at the sediment water interface, and $\beta$ is the depth-attenuation coefficient. The burial velocity of solids was also assumed to conform to steady-state compaction and, following the conservation of mass (e.g. Berner, 1980):

$w_{i}=w_{\infty} \frac{1-\varphi_{\infty}}{1-\varphi_{i}}$

No externally impressed pore-water advection was detected in the sediment (Rühlemann et al., 2012). Thus the velocity at compaction of both the solid phase and the aqueous phase was assumed to be the same value $\left(w_{\infty}=v_{\infty}\right)$. The pore-water velocity also conforms to conservation of mass: 


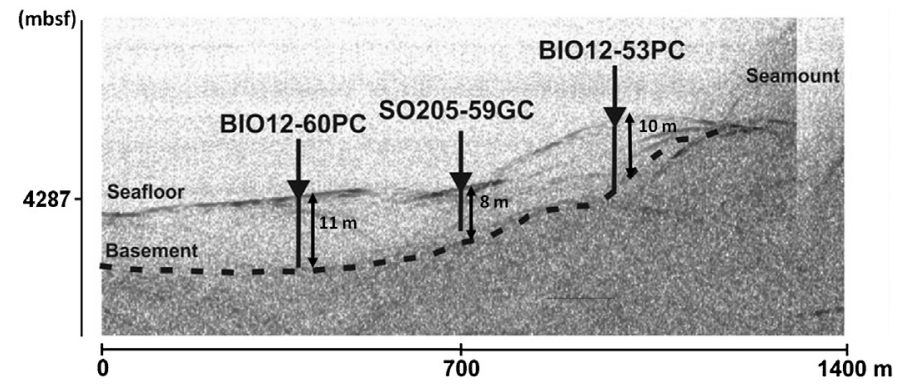

Fig. 2. E-W sediment echosounder profile along the sampling sites at the western foot of the Teddy Bare seamount. Sediment thickness at each site is displayed to the right of the sampled cores.

$v_{i}=v_{\infty} \frac{\varphi_{\infty}}{\varphi_{i}}$

Note that due to significant sediment loss from the top of core BI012-60PC no numerical simulation was applied to this site.

\section{Results}

\subsection{Sediment description}

The sediment echosounder profile shows a sediment thickness of $\sim 11 \mathrm{~m}$ for site BIO12-60PC, $\sim 8 \mathrm{~m}$ for site SO205-59GC and $\sim 10 \mathrm{~m}$ for site BI012-53PC (Fig. 2). High resolution bathymetry and acoustic mapping of the area was done during a RV KILO MOANA cruise in 2008 (Rühlemann et al., 2011).

The sediments at all sites mainly consist of radiolaria- and diatom-bearing silty clay. Distinct and repeated color changes occur throughout all sediment cores ranging from pale yellowishbrown through brownish to dark brown colors. At site BIO12-60PC (supplemental material, 1a) the uppermost $\sim 70 \mathrm{~cm}$ of sediment were lost during the coring process. The sediment mainly consists of dark to dark-brown silty clay with a few ring-shaped bioturbation patches. Dark layers, which are present at $\sim 1 \mathrm{~m}$ below seafloor (mbsf) are probably rich in manganese. Manganese nodules and fragments were found at $4.2 \mathrm{mbsf}$ and $9.3 \mathrm{mbsf}$. The sediment at site SO205-59GC (supplemental material, 1b) is characterized by several layers consisting of colored fragments of scoria (6-6.1 mbsf) and is intensely bioturbated. The bottom of this core contained fragments of basaltic crust. The sediments of the MUC (SO205-65MUC) retrieved at this site are also characterized by strong bioturbation. Site BIO12-53PC (supplemental material, 1c), which is located closest to the Teddy Bare seamount showed turbulent bedding at core depths between 3.2 and 8.7 mbsf. Below a depth of 8.7 mbsf the sediments are almost homogeneous.

\subsection{Ex situ oxygen measurements}

All sediment cores retrieved display similar oxygen concentration profiles. Oxygen concentrations decrease gradually with depth down to $\sim 4 \mathrm{mbsf}$ at site BI012-60PC, to $\sim 3 \mathrm{mbsf}$ at site SO205-59GC and to $\sim 7$ mbsf at site BIO12-53PC (Fig. 3) to oxygen concentrations of $\sim 30 \mu \mathrm{mol} / \mathrm{l}$, and then increase downward towards the bottom of the cores. Oxygen concentrations in pore water are $\sim 125 \mathrm{mmoll}^{-1}$ at the top of core BIO12-60PC and $\sim 155 \mu \mathrm{moll}^{-1}$ at the top of core BIO12-53PC. At site SO205-59GC (SO205-65MUC) bottom water concentrations are $\sim 160 \mu \mathrm{moll}^{-1}$ and decrease sharply within the uppermost $10 \mathrm{~cm}$ of the sediment core (Fig. 3).

\subsection{Pore water and solid phase}

Nitrate concentrations at the top of the three piston and gravity cores as well as the MUC (SO205-65MUC) are between
40-50 $\mu \mathrm{moll}^{-1}$ and slightly increase in the upper $20 \mathrm{~cm}$ of the sediment at sites SO205-59GC (Fig. 3b) and BIO12-53PC (Fig. 3c). Nitrate bottom water concentration at site SO205-65MUC are about $37 \mathrm{mmoll}^{-1}$. At all three sites, nitrate concentrations then slightly decrease with depth down to about $40 \mu \mathrm{moll}^{-1}$ (Fig. 3).

Pore-water phosphate concentrations in core SO205-59GC are about $2 \mu \mathrm{moll}^{-1}$ and stay nearly constant over depth (Fig. 3b). At cores BIO12-60PC (Fig. 3a) and BIO12-53PC (Fig. 3c) the phosphate concentrations fluctuate around $3 \mu \mathrm{moll}^{-1}$ and show a subtle decreasing trend with sediment depth. Phosphate bottom water concentration at site SO205-65MUC are about $2 \mu \mathrm{moll}^{-1}$.

The TOC content at the top of core SO205-65MUC (site 59GC) amounts to $0.58 \mathrm{wt} \%$ (Fig. 3). The surface sediment at the other two sites was lost during coring. Below $2 \mathrm{~m}$ core depth the TOC contents at sites SO205-59GC and BI012-60PC stay constant at about $0.1 \mathrm{wt} \%$ while they even drop to values between 0.02 and $0.03 \mathrm{wt} \%$ in core BIO12-53PC (Fig. 3c).

\section{4. ${ }^{87} \mathrm{Sr} /{ }^{86} \mathrm{Sr}$ ratio}

Results of the stable strontium isotope measurements in the bottom water of site S0205-59GC show a ${ }^{87} \mathrm{Sr} /{ }^{86} \mathrm{Sr}$ ratio of about 0.709158 . In the pore waters the ratio decreases down to a value of 0.709140 at a sediment depth of $\sim 1.2 \mathrm{mbsf}$ and stays constant down to $\sim 4$ mbsf (Fig. 4). At 5 mbsf the ${ }^{87} \mathrm{Sr} /{ }^{86} \mathrm{Sr}_{\mathrm{pw}}$ ratio further decreases to 0.709128 and then increases again to a ratio of 0.709152 at $\sim 6.1 \mathrm{mbsf}$.

\subsection{Transport reaction modeling}

Transport reaction simulations were performed for sites SO20559GC and BI012-53PC (Fig. 5), which represent the cores where sediment loss at the surface was at a minimum. The degradation of organic matter (Eqs. (2), (3)) and the oxidation of ammonium (Eqs. (4), (5)) are highest at the top of cores SO205-65MUC and BIO12-53PC. The model parameterization varied for both sites (Table 3). Simulations revealed that organic matter degradation rates are higher at site SO205-59GC as compared to site BI012-53PC. The parameter governing the order of the reaction of organic matter degradation was set to 0.2 for both sites, as it represented the minimum value that would allow an organic matter pool distribution capable of consuming sufficient oxygen at depth to reproduce the determined pore-water geochemistry.

\section{Discussion}

Deep-sea sediments below $2000 \mathrm{~m}$ water depth represent the largest proportion of the global seafloor, yet they receive $<1 \%$ of the global particulate organic carbon fluxes $\left(12 \mathrm{Tg} \mathrm{Cy}^{-1}\right.$, Dunne et al., 2007). The geochemistry of deep-sea sediments is thus generally characterized by low ( $<1 \mathrm{wt} \%$ ) organic matter contents (Smith and Rabouille, 2002) and decimeter- to meter-scale oxygen penetration (e.g., D'Hondt et al., 2009; Fischer et al., 2009).

The contents and depth profiles of organic matter are similar at the top of the cores SO205-59GC and BI012-60PC, exhibiting the typical exponential decrease with depth and agree with other TOC profiles reported for eastern equatorial Pacific Ocean sediments (e.g., Müller et al., 1988; Murray, 1987; Halbach et al., 1988; Khripounoff et al., 2006; Mewes et al., 2014) and the North Pond site of the Atlantic Ocean (Ziebis et al., 2012). The organic matter contents of the sediments at site BI012-53PC are significantly lower than at the other two sites investigated along this transect. The turbulent bedding at site BI012-53PC (which is located closest to the Teddy Bare seamount with the lowest TOC content of all three sites) found at 3.2 and 8.7 mbsf (Supplemental Fig. 1) indicates that the site is affected by mass wasting of sediments from 
a)

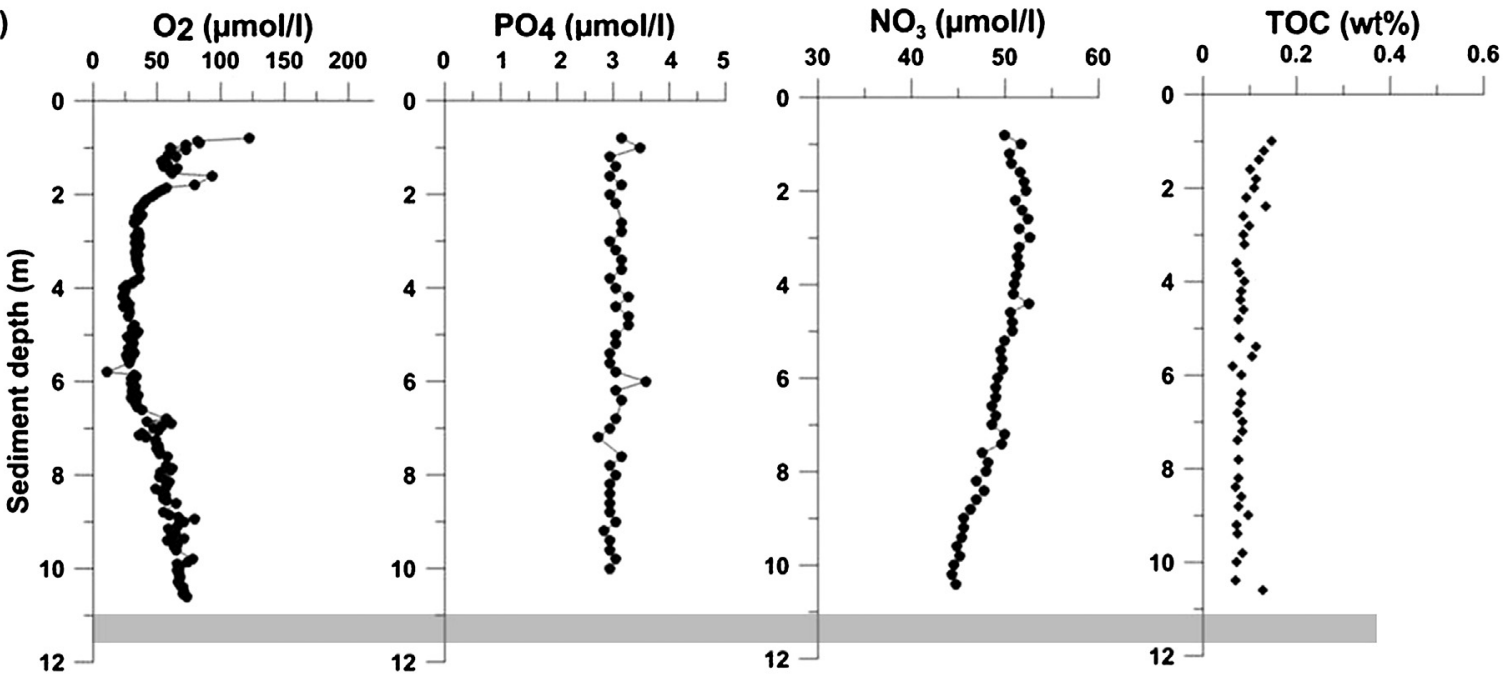

b)

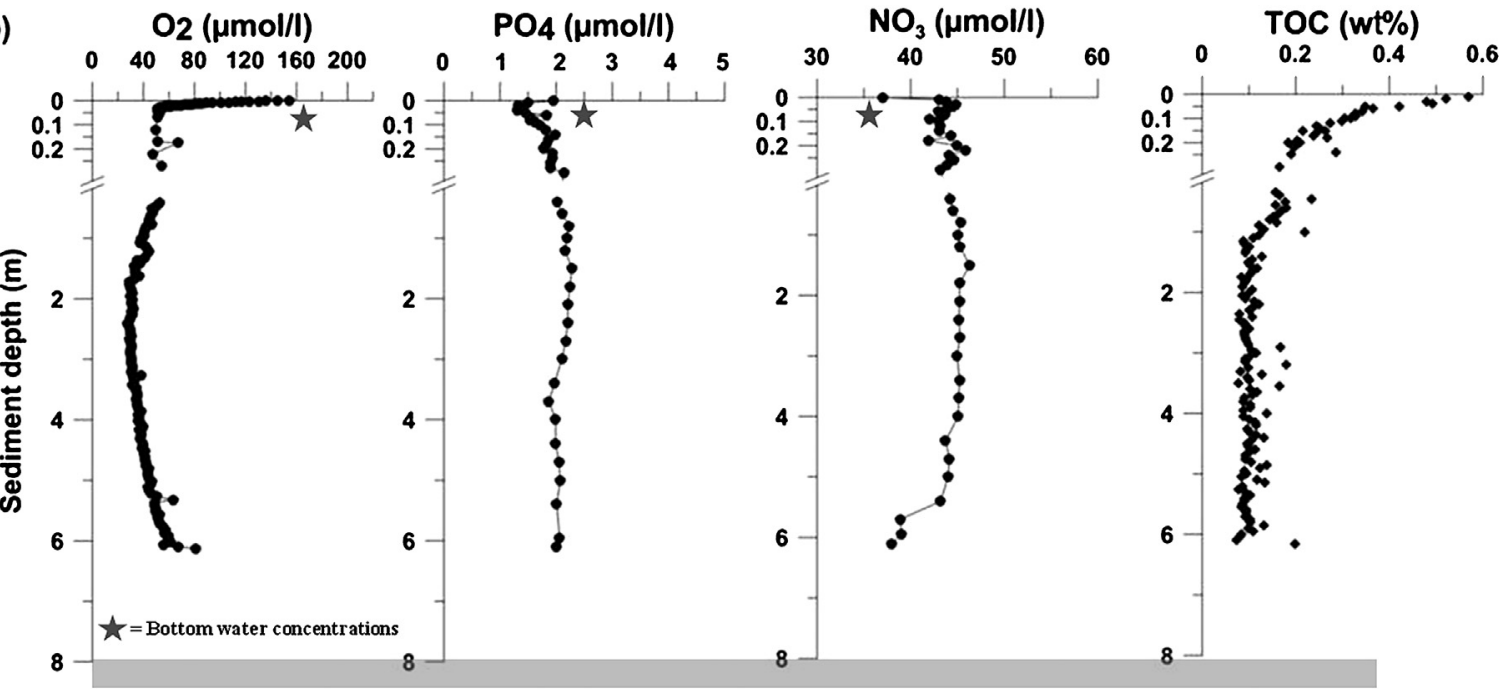

c)
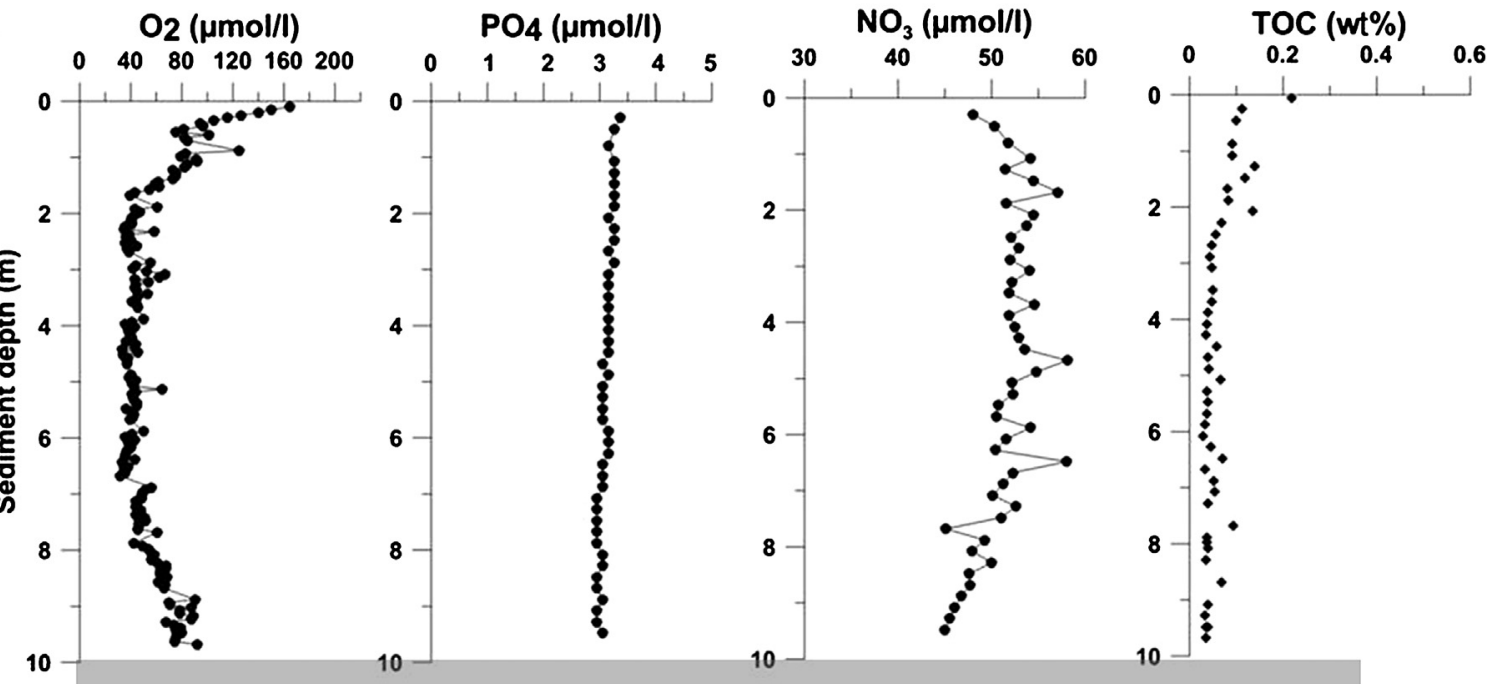

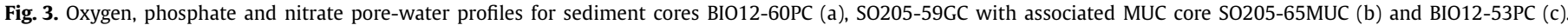

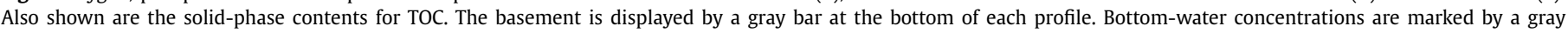




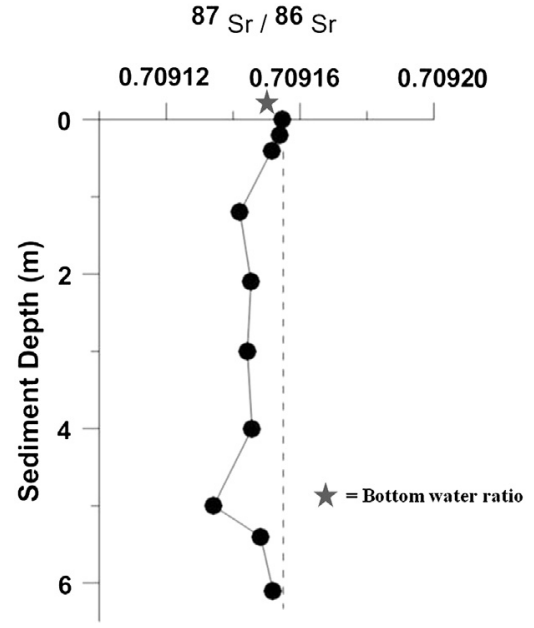

Fig. 4. ${ }^{87} \mathrm{Sr} /{ }^{86} \mathrm{Sr}$ ratio in pore water of site SO205-59GC. ${ }^{87} \mathrm{Sr} /{ }^{86} \mathrm{Sr}$ ratio in the bottom water is displayed with a broken line. The bottom water ratio is marked by a gray star

further up the seamount, which may dilute the influx of organic matter from the water column.

Oxygen concentrations of $155-160 \mu \mathrm{moll}^{-1}$ at the sediment/ water interface at site S0205-59GC (SO205-65MUC) are in general agreement with previously published data for surface sediments in the CCFZ (e.g., Hammond et al., 1996; Khripounoff et al., 2006; Mewes et al., 2014). However, the shapes of the oxygen profiles measured at the three sites along the transect at the foot of the Teddy Bare seamount significantly differ from oxygen concentration profiles measured at other sites in the eastern CCFZ, which are commonly characterized by complete oxygen consumption at a sediment depth of $\sim 2-3 \mathrm{~m}$ (Mewes et al., 2014). The oxygen profiles for the three sites presented here exhibit a decreasingwith-depth oxygen profile down to a minimum around 3-4 mbsf, followed by a subsequent increase in oxygen concentrations with sediment depth until the basaltic basement rock. These oxygen profiles are the first such oxygen profiles reported for the CCFZ. Several other sites have been reported where oxygen penetrates down to more than $10 \mathrm{mbsf}$, however, the shape of the oxygen profiles significantly differs from those reported here (e.g., D'Hondt et al., 2009; Fischer et al., 2009; Røy et al., 2012). The low rates of oxygen consumption observed at the sites investigated by D'Hondt et al. (2009), Fischer et al. (2009) and Røy et al. (2012) have been shown to result from the extremely low burial fluxes of organic matter. Although oxygen persists throughout the entire sediment column in the SPG and reaches the basaltic basement, these locations are characterized by extremely low sedimentation and respiration rates. Oxygen concentration profiles similar to those reported here, with an increase towards the basalt, have been documented in other locations within the Pacific Ocean (e.g. the equatorial Pacific and the Peru Basin, D'Hondt et al., D'Hondt et al., 2004; IODP 1371 and 1369 sites, D'Hondt et al., 2015) and in small sediment-filled ponds overlying basaltic crust on the flank of the Mid-Atlantic Ridge (Ziebis et al., 2012; Orcutt et al., 2013). These authors suggested that oxygen and nitrate pore-water profiles exhibit trends indicative of diffusive exchange of solutes between the basaltic basement and the overlying sediment (Fig. 3). Ziebis et al. (2012) proposed that oxygen diffuses upwards into the overlying sediment, and creates the observed oxygen pore-water profiles that show increasing oxygen concentrations towards the basement. We suggest that the oxygen profiles shown in this study (Fig. 3) result from similar interaction between oxic fluids circulating within the seamount crust and the sediments overlying the basalt.
The oxygen concentrations of $60-90 \mu \mathrm{M}$ measured at the bottom of the sediment cores are significantly lower than at the sediment/water interface and in the bottom water. This finding agrees with results obtained for the sediments of the North Pond site in the Atlantic Ocean (Ziebis et al., 2012; Orcutt et al., 2013) where oxygen concentrations of $\sim 220 \mu \mathrm{mol}$ (site 13502) were determined in sediments directly above the basaltic basement while the corresponding bottom-water oxygen concentrations were $\sim 259 \mu \mathrm{M}$. This difference in oxygen concentrations has been attributed to oxygen-consuming biotic and abiotic processes within the basaltic crust (Wheat and Fisher, 2008; Orcutt et al., 2013). Since basaltic rocks are highly enriched in reduced forms of $\mathrm{Fe}, \mathrm{S}$ and $\mathrm{Mn}$, lithoautotrophic microbes can promote oxidative surface reactions for energy gain, when the reduced minerals of the basalt are exposed to oxic seawater (Edwards et al., 2005). The oxidation of reduced $\mathrm{Fe}$ and $\mathrm{S}$ compounds/minerals is by far the most abundant source of energy available to lithoautotrophic organisms (McCollom, 2000; Bach and Edwards, 2003).

$\mathrm{NO}_{3}^{-}$pore-water concentrations of about $\sim 40 \mu \mathrm{moll}^{-1}$ at the bottom of core SO205-59GC (SO205-65MUC) are similar to $\mathrm{NO}_{3}^{-}$ bottom water concentrations determined at the three sites presented here as well as at other sites in the CCFZ investigated by Jeong et al. (1994) and Mewes et al. (2014). The concaveness of the $\mathrm{NO}_{3}^{-}$profiles mirrors those of oxygen, featuring peak concentrations around the mid-depth oxygen minima (Fig. 3). As simulated and shown in Fig. 5 these $\mathrm{NO}_{3}^{-}$profiles are the result of nitrification of ammonium, released during the aerobic degradation of organic matter. $\mathrm{NO}_{3}^{-}$diffuses upward across the sediment/water interface and downward into the basaltic basement.

Pore-water $\mathrm{PO}_{4}^{3-}$ concentrations at the sediment surface of site SO205-59GC (top of core SO205-65MUC) are comparable to $\mathrm{PO}_{4}^{3-}$ data of other sites investigated in the CCFZ area (Jeong et al., 1994; Khripounoff et al., 2006). $\mathrm{PO}_{4}^{3-}$ behaves mostly conservatively, fluctuating around bottom water concentrations (Fig. 3), indicating that the phosphorous release during organic matter degradation is insufficient to significantly affect the $\mathrm{PO}_{4}^{3-}$ profiles.

At Dorado outcrop, Wheat and Fisher (2008), and Hutnak et al. (2008) found that phosphate and nitrate concentrations of porewater samples collected directly above the basaltic basement differed only slightly from the bottom-water concentrations of these dissolved constituents in the area. Wheat and Fisher (2008) postulated that reactions between seawater and basalt could lead to phosphate precipitation. However, $\mathrm{PO}_{4}^{3-}$ concentrations at the three Teddy Bare sites are only slightly lower directly above the basement in comparison to the determined seawater concentrations and the pore-water concentrations measured in the sediments above. This minor removal in the basaltic basement may indicate that the area of recharge is nearby and only little interaction between seawater and basalt has taken place.

Further evidence for seawater circulation through the seamount crust and diffusive exchange of solutes between the basaltic basement and the overlying sediment is given by the pore water ${ }^{87} \mathrm{Sr} /{ }^{86} \mathrm{Sr}$ isotopic ratio (Fig. 4) (e.g., Baker et al., 1991; Elderfield et al., 1999). The pore-water ${ }^{87} \mathrm{Sr} /{ }^{86} \mathrm{Sr}$ ratio determined at the bottom of core SO205-59GC is similar to the ${ }^{87} \mathrm{Sr} /{ }^{86} \mathrm{Sr}$ isotopic ratio in the bottom water of the associated MUC SO205-65MUC (Fig. 4). Usually, ${ }^{87} \mathrm{Sr}$ is removed from pore water by adsorption onto particle surfaces and thus the ${ }^{87} \mathrm{Sr} /{ }^{86} \mathrm{Sr}$ is expected to decrease continuously with sediment depth. The pore-water ${ }^{87} \mathrm{Sr} /{ }^{86} \mathrm{Sr}$ profile determined at site SO205-59GC displays a decrease only over the uppermost meter. The ${ }^{87} \mathrm{Sr} /{ }^{86} \mathrm{Sr}$ ratio then stays constant between 1 and $4 \mathrm{mbsf}$ and increases with depth below a minimum at 5 mbsf. A similar increase in the pore-water ${ }^{87} \mathrm{Sr} /{ }^{86} \mathrm{Sr}$ isotopic ratio with depth toward the basaltic basement was previously described at DSDP site 572 within the southern CCFZ by Baker et al. (1991). The ratio determined here is slightly lower than the 

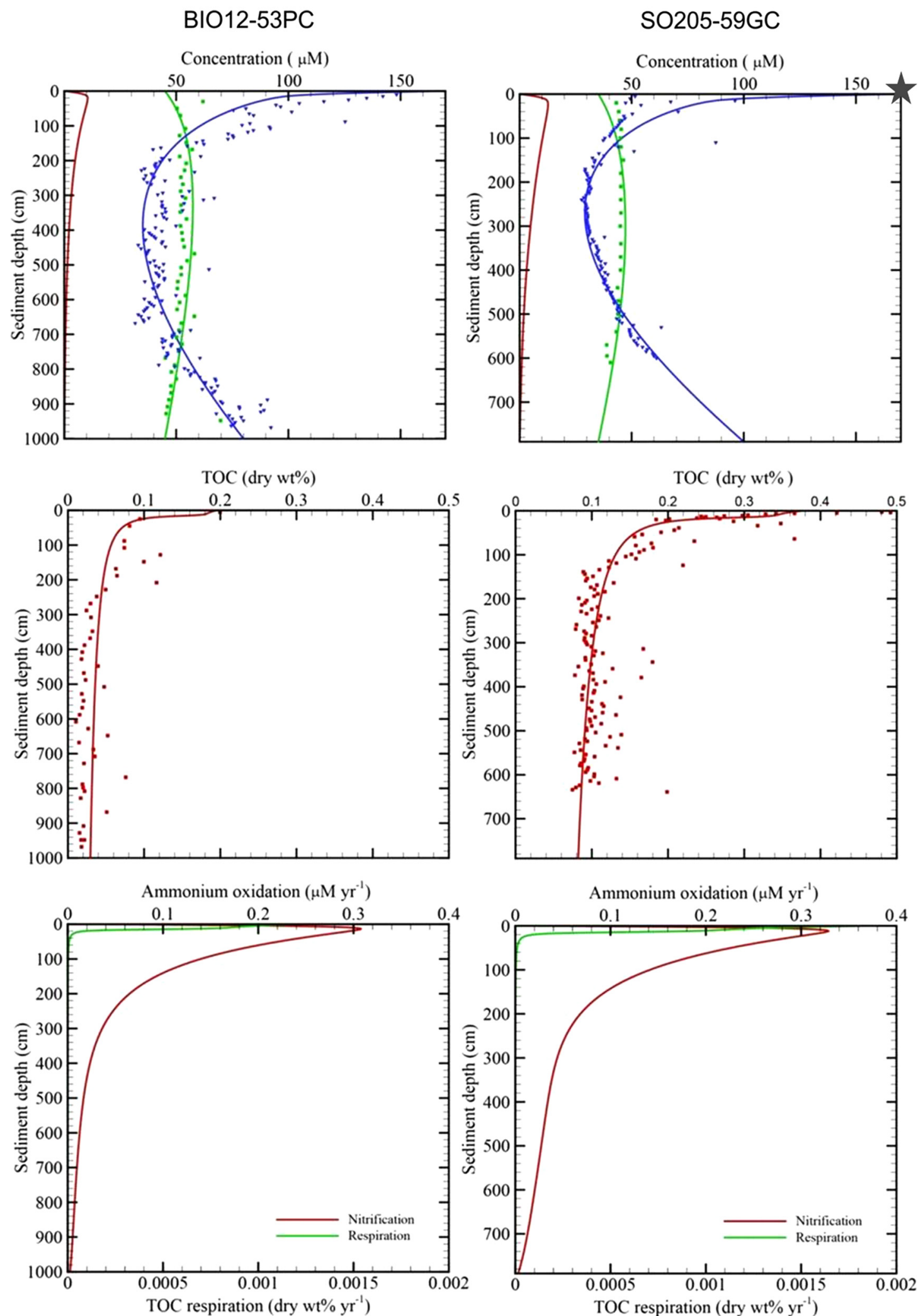

$=$ Bottom water concentrations

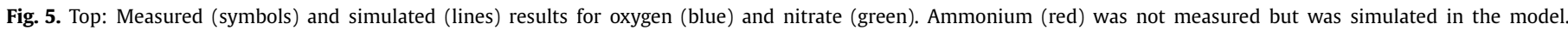

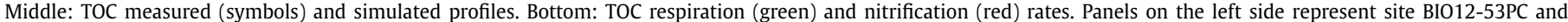
on the right side SO205-59GC (with associated MUC core SO205-65MUC). Bottom-water concentrations are marked by a gray star. 
Table 3

Parameters used in the reaction-transport model (note that all parameters derived for this study are based on model fit).

\begin{tabular}{|c|c|c|c|c|}
\hline Name & Symbol & Unit & $\begin{array}{l}\text { Site } \\
\text { SO205-59GC }\end{array}$ & $\begin{array}{l}\text { Site } \\
\text { BI012-53PC }\end{array}$ \\
\hline Porosity at the sediment-water interface & $\varphi_{0}$ & - & & \\
\hline Porosity at depth & $\varphi_{\infty}$ & - & & \\
\hline Porosity attenuation & $\beta$ & $\mathrm{cm}^{-1}$ & & \\
\hline Depth to biomixing half values & $z_{\text {mix }}$ & $\mathrm{cm}$ & 5 & 5 \\
\hline Biomixing attenuation & $z_{a t t}$ & $\mathrm{~cm}$ & 5 & 5 \\
\hline Reference bioturbation coefficient & $D_{b, 0}$ & $\mathrm{~cm}^{2} \mathrm{yr}^{-1}$ & 3 & 6 \\
\hline Reference bioirrigation coefficient & $\alpha_{0}$ & $\mathrm{yr}^{-1}$ & 0.5 & 0 \\
\hline TOC degradation apparent order & $\sigma$ & - & 0.2 & 0.25 \\
\hline Average age of labile pools & $a$ & $\mathrm{yr}$ & 40 & 40 \\
\hline Ammonium oxidation rate constant & $k_{\text {amox }}$ & $\mu \mathrm{M}^{-1} \mathrm{yr}^{-1}$ & 0.0011 & 0.0011 \\
\hline Burial velocity at depth & $w_{\infty}$ & $\mathrm{cm} \mathrm{kyr}^{-1}$ & 0.38 & 10.0 \\
\hline
\end{tabular}

Table 4

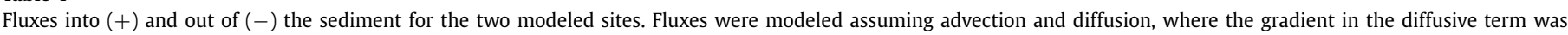
approximated using a hermetic cubic spline around the sediment-water and the sediment-basalt interfaces.

\begin{tabular}{|c|c|c|c|c|c|c|}
\hline Species & Name & Unit & $\begin{array}{l}\text { Sediment-water } \\
\text { BI012-53PC }\end{array}$ & $\begin{array}{l}\text { Sediment-basalt } \\
\text { BI012-53PC }\end{array}$ & $\begin{array}{l}\text { Sediment-water } \\
\text { SO205-59GC }\end{array}$ & $\begin{array}{l}\text { Sediment-basalt } \\
\text { Site SO205-59GC }\end{array}$ \\
\hline $\mathrm{O}_{2}$ & dissolved oxygen & $\mathrm{nmol} \mathrm{cm} \mathrm{cm}^{-2} \mathrm{y}^{-1}$ & $2.6 \mathrm{e} 3$ & $3.4 \mathrm{e} 1$ & $3.2 \mathrm{e} 3$ & $6.3 e 1$ \\
\hline $\mathrm{NH}_{4}^{+}$ & ammonium & $\mathrm{nmol} \mathrm{cm} \mathrm{c}^{-2} \mathrm{y}^{-1}$ & $-3.4 \mathrm{e} 2$ & -0.38 & $-4.3 e 2$ & -1.2 \\
\hline $\mathrm{NO}_{3}-$ & nitrate & $\mathrm{nmol} \mathrm{cm}{ }^{-2} \mathrm{y}^{-1}$ & -29 & -6.6 & -28 & -9.0 \\
\hline
\end{tabular}

value of 0.70920 found by Baker et al. (1991) for the CCFZ and that determined by Elderfield et al. (1999) near the Juan de Fuca ridge $\left({ }^{87} \mathrm{Sr} /{ }^{86} \mathrm{Sr}_{\mathrm{sw}}=0.70916\right)$. A study by Voigt et al. (2015) determined similar ratios in the equatorial Pacific near Hawaii. ${ }^{87} \mathrm{Sr}$ is also removed from the seawater by adsorption when it flows through the basaltic basement. In general, basalt has an initial magmatic value $\left({ }^{87} \mathrm{Sr} /{ }^{86} \mathrm{Sr}_{\text {basalt }}\right)$ of 0.70260 but higher values of ${ }^{87} \mathrm{Sr} /{ }^{86} \mathrm{Sr}_{\text {basalt }}(0.70512-0.70842)$ have also been measured (Menzies and Seyfried, 1979). The similar ${ }^{87} \mathrm{Sr} /{ }^{86} \mathrm{Sr}$ isotopic ratios determined for the pore water in the basal sediments and in the bottom water at site SO205-59GC support the notion that the recharge area, where seawater enters the basalt, is nearby and only little interaction between seawater and the basalt has taken place. Furthermore, similar ${ }^{87} \mathrm{Sr} /{ }^{86} \mathrm{Sr}$ isotopic ratios at the bottom of the sediment cores and the bottom water indicate that the basaltic basement has a relatively low temperature (Teagle et al., 1998; James et al., 2003), since strontium reacts relatively fast within the basaltic basement at high temperatures $\left(40-60{ }^{\circ} \mathrm{C}\right.$; Fisher and Wheat, 2010), and thus the pore water ${ }^{87} \mathrm{Sr} /{ }^{86} \mathrm{Sr}$ isotopic ratio at the bottom of the sediments would likely be much lower (Butterfield et al., 2001).

The diffusive oxygen exchange between seawater flowing through the basaltic crust and the overlying sediment represents an important source of oxygen and induces a reversed redox zonation in the basal sediments. A similar input of oxidants/solutes, namely sulfate, from below has also been reported and modeled for the hydrological system of the Costa Rica subduction zone by Haeckel (2006). The author demonstrated that cold seawater circulating in the oceanic basement induces an upward diffusion of sulfate into the overlying sediment column, and by this way significantly affecting biogeochemical processes in these deposits. Although upward oxygen diffusion from the basaltic crust contributes only $2.0 \%$ and $1.3 \%$ of the total oxygen flux at sites SO205-59GC and BIO12-53PC respectively (Table 4), this additional oxygen flux into the sediment occurs at a sediment depth where respiration rates are orders of magnitude lower than at the sediment surface (Fig. 5). Thus, the diffusive flux of oxygen from the basaltic basement outpaces the oxygen consumption though organic matter respiration and nitrification, and oxygen remains present throughout the sediment column. Nutrient exchange between the sediment and the underlying basaltic crust occurs at lower rates than between the sediment and the overlying bottom water. Nitrate diffuses upward from the sediment into the water column at a rate of $29 \mathrm{nmol} \mathrm{cm}{ }^{-2} \mathrm{yr}^{-1}$ and $28 \mathrm{nmol} \mathrm{cm}{ }^{-2} \mathrm{yr}^{-1}$ at sites S0205-59GC and BI012-53PC respectively, while it diffuses downward into the basalt at a rate of $9 \mathrm{nmol} \mathrm{cm}^{-2} \mathrm{yr}^{-1}$ and $6.5 \mathrm{nmol} \mathrm{cm}^{-2} \mathrm{yr}^{-1}$ for the same sites, respectively (Table 4). Due to the relatively low rates of organic matter degradation, the release of phosphate is minor, and the profile exhibits little variation throughout the sediment.

Results from reaction-transport modeling reveal that the bestfit sedimentation rates are $\sim 0.38 \mathrm{~cm} \mathrm{kyr}^{-1}$ and $\sim 10 \mathrm{~cm} \mathrm{kyr}^{-1}$, for sites SO205-59GC and BI012-53PC, respectively. The total accumulation of $8-10 \mathrm{~m}$ of sediment since the formation of the basaltic crust 19-20 Ma ago leads to average sedimentation rates of $0.4-0.5 \mathrm{~cm} \mathrm{kyr}^{-1}$ (Barckhausen et al., 2013). These values fit very well with the sedimentation rate modeled for site SO205-59GC.

The turbulent bedding sedimentary facies found below $3.2 \mathrm{~m}$ core depth in BI012-53PC indicates sediment slumping from the Teddy Bare seamount to this site which is the most proximal of the three sites investigated and well explains the significantly higher sedimentation rate. As shown by Jeong et al. (1994) slumping and mass wasting are widespread sediment transport processes at seamount flanks in the CCFZ. Nevertheless, since the sediments above $\sim 3.2 \mathrm{~m}$ sediment depth at site BI012-53PC are nearly homogeneous and the model-derived sedimentation rate for this site is $\sim 10 \mathrm{~cm} \mathrm{kyr}^{-1}$, the oxygen in the sediments has had sufficient time ( $\sim 32 \mathrm{kyr})$ to equilibrate to the present-day conditions resulting in the similar concave shapes of the oxygen profiles at the three sites.

\section{Conclusion and implications}

We investigated three sites located on a transect at the foot of a seamount in the Clarion-Clipperton Fracture Zone of the equatorial Pacific Ocean. TOC measurements revealed that the sediments of all sites are characterized by low organic matter contents in the range of $0.1-0.2 \mathrm{wt} \%$ below a sediment depth of $20 \mathrm{~cm}$. Pore-water oxygen concentrations display a downward decrease in the uppermost few meters, a mid-depth minima around $20-40 \mu \mathrm{moll}^{-1}$, and further down an increase with depth toward the sedimentseamount basement interface. The nitrate profiles mirror those 
of oxygen, featuring peak concentrations around the mid-depth oxygen minima. These results indicate an upward diffusive flux of oxygen from the underlying permeable basaltic basement into the overlying sediments, and a counter-directed flux of nitrate towards the sediment-basement interface. This phenomenon is furthermore supported by a pore-water ${ }^{87} \mathrm{Sr} /{ }^{86} \mathrm{Sr}$ isotopic ratio in the basal sediments that is close to the ${ }^{87} \mathrm{Sr} /{ }^{86} \mathrm{Sr}$ isotopic ratio in the bottom water. Our results demonstrate that the diffusive transfer of oxygen from the underlying seamount basaltic basement represents an important additional transport mechanism of oxidants into these deep-ocean deposits. The two sources of oxygen (the bottom water and the seawater circulating in the basaltic basement) produce a fully oxic sediment column that significantly contrasts other "non-seamount" sites in the study area, which are commonly characterized by oxygen penetration depths of 2-3 mbsf. We infer a strong impact of oxic conditions throughout the sediments on organic matter preservation and therefore, a strong influence on the microbial activity in the sediments.

The CCFZ is one of the areas with highest abundance of manganese nodules on Earth. It is also strewn with ten thousands of seamounts, and thus with possible recharge sites of oxic seawater into the basaltic seamount crust like those presented in this study. Future studies of manganese nodules in this area must consider the possible effects of oxygen recharge from the basaltic crust on the composition of manganese nodules.

Seamounts represent specific ecological niches as their height typically rises several hundreds of meters above the surrounding abyssal plain, and thus are often subjected to pressures, temperatures and environmental conditions that are different from the abyssal plain. In addition, recharge seamounts are characterized by the geochemistry of the overlying seawater, whereas the ecology of discharge seamounts is controlled by the mixing of seawater and the water emitted from the seamount. This latter water body is subjected to various geochemical processes within the basalts such as pore water-basalt nutrient exchange and oxygen consumption and to diffusive exchanges with the overlying sediments during its transit path.

The interactions between seafloor sediments and underlying basaltic crust may be pervasive throughout discharging and recharging seamounts. Unlike ridge flanks which are overlain by hundreds of meters of sediment, and cannot be easily investigated at high resolution, the study of geochemical fluxes and processes near seamounts and other crustal outcrops can offer a glimpse into the hydrothermically-induced biogeochemical and heat exchanges between sediments, oceanic crust and seawater. These studies can thus increase our understanding of biogeochemical cycles and microbial communities in these environments.

\section{Acknowledgements}

We thank the captain and crew of RV SONNE cruise SO-205 and RV L'ATALANTE cruise BIONOD. We are indebted to Prof. Dr. Heiner Villinger for his constructive comments and for reading an earlier draft of this manuscript. We would like to thank Ingrid Stimac, Ludmila Baumann and Jennifer Ciomber (all AWI Bremerhaven) for their great support in the laboratory and Jan Hansen for his support onboard RV SONNE and RV L'ATALANTE. This research was funded by the Bundesministerium für Bildung und Forschung (BMBF, grant number 03G0205).

We acknowledge further financial support from the Helmholtz Association (Alfred Wegener Institute Helmholtz Centre for Polar and Marine Research, Bremerhaven). Additional funding was provided by the EU H2020 (MSCA award No. 661163 to JMM). The full set of pore-water and solid-phase data is available via the geological data network PANGAEA (http://www.pangaea.de; http://dx.doi.org/10.1594/PANGAEA.853828).

\section{Appendix A. Supplementary material}

Supplementary material related to this article can be found online at http://dx.doi.org/10.1016/j.epsl.2015.10.028.

\section{References}

Bach, W., Edwards, K.J., 2003. Iron and sulfide oxidation within the basaltic ocean crust - extent, processes, timing, and implications for chemolithoautotrophic primary biomass production. Geochim. Cosmochim. Acta 67, 3871-3887.

Baker, P.A., Stout, P.M., Kastner, M., Elderfield, H., 1991. Large-scale lateral advection of seawater through oceanic-crust in the central equatorial Pacific. Earth Planet. Sci. Lett. 105, 522-533.

Barckhausen, U., Bagge, M., Wilson, D.S., 2013. Seafloor spreading anomalies and crustal ages of the Clarion-Clipperton Zone. Mar. Geophys. Res. 34, 79-88.

Berger, W.H., 1989. Global maps of ocean productivity. In: Berger, W.H., Smetacek, V.S., Wefer, G. (Eds.), Productivity of the Ocean: Present and Past. J. Wiley \& Sons, Chichester, pp. 429-455.

Berner, R.A., 1980. Early Diagenesis: A Theoretical Approach. Princeton University Press, Princeton, pp. 1-241.

Berner, R.A., 1981. A new geochemical classification of sedimentary environments. J. Sediment. Petrol. 51, 359-365.

Boudreau, B.P., 1997. Diagenetic Models and Their Implementations. Springer-Verlag, Berlin. 414 pp.

Boudreau, B.P., Ruddick, B., 1991. On a reactive continuum representation of organicmatter diagenesis. Am. J. Sci. 291, 507-538.

Bowles, M.W., Mogollón, J.M., Kasten, S., Zabel, M., Hinrichs, K.U., 2014. Global rates of marine sulfate reduction and implications for sub-sea-floor metabolic activities. Science 344 (6186), 889-891.

Butterfield, D.A., Nelson, B.K., Wheat, C.G., Mottl, M.J., Roe, K.K., 2001. Evidence for basaltic $\mathrm{Sr}$ in midocean ridge-flank hydrothermal systems and implications for the global oceanic Sr isotope balance. Geochim. Cosmochim. Acta 65, 4141-4153.

Dickens, G.R., Kölling, M., Smith, D.C., Schnieders, L., 2007. Rhizon sampling of pore waters on scientific drilling expeditions: an example from the IODP Expedition 302, Arctic Coring Expedition (ACEX). Sci. Drill., 1-4.

D'Hondt, S., et al., 2004. Distributions of microbial activities in deep subseafloor sediments. Science 306 (5705), 2216-2221.

D'Hondt, S., Inagaki, F., Zarikian, C.A., Abrams, L.J., Dubois, N., Engelhardt, T., Evans, H., Ferdelman, T., Gribsholt, B., Harris, R.N., Hoppie, B.W., Hyun, J.-H., Kallmeyer J., Kim, J., Lynch, J.E., McKinley, C.C., Mitsunobu, S., Morono, Y., Murray, R.W. Pockalny, R., Sauvage, J., Shimono, T., Shiraishi, F., Smith, D.C., Smith-Duque, C.E. Spivack, A.J., Steinsbu, B.O., Suzuki, Y., Szpak, M., Toffin, L., Uramoto, G., Yamaguchi, Y.T., Zhang, G., Zhang, X.-H., Ziebis, W., 2015. Presence of oxygen and aerobic communities from sea floor to basement in deep-sea sediments. Nat. Geosci. 8, 299-304. http://dx.doi.org/10.1038/ngeo2387.

D’Hondt, S., Spivack, A.J., Pockalny, R., Ferdelman, T.G., Fischer, J.P., Kallmeyer, J., Abrams, L.J., Smith, D.C., Graham, D., Hasiuk, F., Schrum, H., Stancin, A.M., 2009. Subseafloor sedimentary life in the South Pacific Gyre. Proc. Natl. Acad. Sci. 106, 11651-11656.

Dunne, J.P., Sarmiento, J.L., Gnanadesikan, A., 2007. A synthesis of global particle export from the surface ocean and cycling through the ocean interior and on the seafloor. Glob. Biogeochem. Cycles 21, GB4006.

Edwards, K.J., Bach, W., McCollom, T.M., 2005. Geomicrobiology in oceanography: microbe-mineral interactions at and below the seafloor. Trends Microbiol. 13 (9), 449-456

Elderfield, H., Wheat, C.G., Mottl, M.J., Monnin, C., Spiro, B., 1999. Fluid and geochemical transport through oceanic crust: a transect across the eastern flank of the Juan de Fuca Ridge. Earth Planet. Sci. Lett. 172, 151-165.

Fischer, J.P., Ferdelman, T.G., D’Hondt, S., Røy, H., Wenzhöfer, F., 2009. Oxygen penetration deep into the sediment of the South Pacific gyre. Biogeosciences 6, 1467-1478

Fisher, A.T., Davis, E.E., Hutnak, M., Spiess, V., Zühlsdorff, L., Cherkaoui, A., Christiansen, L., Edwards, K., Macdonald, R., Villinger, H., Mottl, M.J., Wheat, C.G. Becker, K., 2003. Hydrothermal recharge and discharge across $50 \mathrm{~km}$ guided by seamounts on a young ridge flank. Nature 421, 618-621.

Fisher, A.T., Wheat, C.G., 2010. Seamounts as conduits for massive fluid, heat, and solute fluxes on ridge flanks. Oceanography 23 (1), 74-100.

Froelich, P.N., Klinkhammer, G.P., Bender, M.L., Luedtke, N.A., Heath, G.R., Cullen, D., 1979. Early oxidation of organic matter in pelagic sediments of the eastern equatorial Atlantic: suboxic diagenesis. Geochim. Cosmochim. Acta 43 (7), 1075-1090.

Grasshoff, K., Kremling, K., Ehrhardt, M., 1999. Methods of Seawater Analysis, 3rd ed. Wiley, Weinheim, p. 600.

Haeckel, M., 2006. A transport-reaction model of the hydrological systems of the Costa Rica subduction zone. In: Morris, J.D., Villinger, H.W., Klaus, A. (Eds.), Proc. ODP, Scientific Results, vol. 205, pp. 1-26. 
Halbach, P., Friedrich, G., von Stackelberg, U., 1988. The Manganese Nodule Belt of the Pacific Ocean. Enke, Stuttgart, p. 254.

Hammond, D.E., McManus, J., Berelson, W.M., Kilgore, T.E., Pope, R.H., 1996. Early diagenesis of organic material in equatorial Pacific sediments: stoichiometry and kinetics. Deep-Sea Res., Part 1 43, 1365-1412.

Haxby, W.F., Weissel, J.K., 1986. Evidence for small-scale mantle convection from Seasat altimeter data. J. Geophys. Res. 91, 3507-3520.

Hutnak, M., Fisher, A.T., Davis, E., Zuehlsdorff, L., Speiss, V., Cherkaoui, A., Villinger, H., 2001. Seamounts as conduits for hydrothermal fluid discharge and recharge: examples from the eastern flank of the Juan de Fuca Ridge, Cascadia Basin. In: AGU Fall Meeting Abstracts, vol. 1, p. 0561.

Hutnak, M., Fisher, A.T., Harris, R., Stein, C., Wang, K., Spinelli, G., Schindler, M., Villinger, H., Silver, E., 2008. Large heat and fluid fluxes driven through midplate outcrops on ocean crust. Nat. Geosci. 1, 611-614.

James, R.H., Allen, D.E., Seyfried, W.E.J., 2003. An experimental study of alteration of oceanic crust and terrigenous sediments at moderate temperatures (51 to $350^{\circ} \mathrm{C}$ ): insights as to chemical processes in near-shore ridge-flank hydrothermal systems. Geochim. Cosmochim. Acta 67, 681-691.

Jeong, K.S., Kang, J.K., Chough, S.K., 1994. Sedimentary processes and manganesenodule formation in the Korea deep-ocean study (Kodos) area, western part of Clarion-Clipperton Fracture-Zones, northeast equatorial Pacific. Mar. Geol. 122, 125-150.

Khripounoff, A., Caprais, J.C., Crassous, P., Etoubleau, J., 2006. Geochemical and biological recovery of the disturbed seafloor in polymetallic nodule fields of the Clipperton-Clarion Fracture Zone (CCFZ) at 5000-m depth. Limnol. Oceanogr. 51, 2033-2041.

McCollom, T.M., 2000. Geochemical constraints on primary productivity in submarine hydrothermal vent plumes. Deep-Sea Res., Part 1 47, 85-101.

Menzies, M., Seyfried, W.E., 1979. Basalt-seawater interaction: trace element and strontium isotopic variations in experimentally altered glassy basalt. Earth Planet. Sci. Lett. 44, 463-472.

Mewes, K., Mogollón, J.M., Picard, A., Rühlemann, C., Kuhn, T., Nöthen, K., Kasten, S. 2014. Impact of depositional and biogeochemical processes on small scale variations in nodule abundance in the Clarion-Clipperton Fracture Zone. Deep-Sea Res., Part 1 91, 125-141. http://dx.doi.org/10.1016/j.dsr.2014.06.001.

Mogollón, J.M., Dale, A.W., Fossing, H., Regnier, P., 2012. Timescales for the development of methanogenesis and free gas layers in recently-deposited sediments of Arkona Basin (Baltic Sea). Biogeosciences 9, 1915-1933. http://dx.doi.org/ 10.5194/bg-9-1915-2012.

Mottl, M.J., Wheat, G., Baker, E., Becker, N., Davis, E., Feely, R., Sansone, F., 1998 Warm springs discovered on 3.5 Ma oceanic crust, eastern flank of the Juan de Fuca Ridge. Geology 26 (1), 51-54.

Müller, P.J., Hartmann, M., Suess, E., 1988. The chemical environment of pelagic sediments. In: Halbach, P., Friedrich, G., von Stackelberg, U. (Eds.), The Manganese Nodule Belt of the Pacific Ocean. Enke, Stuttgart, p. 254.

Murray, J.W., 1987. Spatial and temporal variations in sediment accumulation in the central tropical Pacific. PhD thesis. Oregon State University.

Orcutt, B., Wheat, C.G., Rouxel, O., Hulme, S., Edwards, K., Bach, W., 2013. Oxygen consumption rates in subseafloor basaltic crust derived from a reaction transport model. Nat. Commun. 4, 2539. http://dx.doi.org/10.1038/ncomms3539.

Revsbech, N.P., 1989. An oxygen microsensor with a guard cathode. Limnol. Oceanogr. 34, 474-478.
Røy, H., Kallmeyer, J., Adhikari, R.R., Pockalny, R., Jørgensen, B.B., D’Hondt, S., 2012. Aerobic microbial respiration in 86-million-year-old deep-sea red clay. Science 336, 922-925.

Rudnicki, M.D., Elderfield, H., Spiro, B., 2001. Fractionation of sulfur isotopes during bacterial sulfate reduction in deep ocean sediments at elevated temperatures. Geochim. Cosmochim. Acta 65 (5), 777-789.

Rühlemann, C., Albers, L., Briand, P., Brulport, J.-P., Cosson, R., Dekov, V.M., Galéron, J., Goergens, R., Gueguen, B., Hansen, J., Kaiser, S., Kefel, O., Khripounoff, A., Kuhn, T., Larsen, K., Menot, L., Mewes, K., Miljutin, D., Mohrbeck, I., Nealova, L., Perret-Gentil, L., Regocheva, A., Wegorzewski, A., Zoch, D., 2012. BIONOD Cruise report, p. 299 .

Rühlemann, C., Baumann, L., Blöthe, M., Bruns, A., Eisenhauer, A., Goergens, R., Hansen, J.W., Heuer, L., Kasten, S., Kuhn, T., Martinez-Arbizu, P., Milyutina, M., Mewes, K., Picard, A., Rutkowski, J., Schott, T., Schückel, S., Schückel, U., Schwarz-Schampera, U., Tiltack, A., Utecht, C., Wohrl, C., Zoch, D., 2010. Cruise report SO-205 MANGAN, microbiology, paleoceanography and biodiversity in the Manganese Nodule Belt of the equatorial NE Pacific, p. 248. http://dx.doi.org/ 10.2312 /cr_so205.

Rühlemann, C., Kuhn, T., Wiedicke, M., Kasten, S., Mewes, K., Picard, A., 2011. Current status of manganese nodule exploration in the German license area. In: Proceedings of the Ninth (2011) ISOPE Ocean Mining Symposium. International Society of Offshore and Polar Engineers (ISOPE), Maui, pp. 168-173.

Seeberg-Elverfeldt, J., Schlüter, M., Feseker, T., Kölling, M., 2005. Rhizon sampling of porewaters near the sediment-water interface of aquatic systems. Limnol. Oceanogr., Methods 3, 361-371.

Smith, C.R., Rabouille, C., 2002. What controls the mixed-layer depth in deep-sea sediments? The importance of POC flux. Limnol. Oceanogr. 47 (2), 418-426.

Teagle, D.A.H., Alt, J.C., Halliday, A.N., 1998. Tracing the chemical evolution of fluids during hydrothermal recharge: constraints from anhydrite recovered in ODP Hole 504B. Earth Planet. Sci. Lett. 155, 167-182.

Voigt, J., Hathorne, E.C., Frank, M., Vollstaedt, H., Eisenhauer, A., 2015. Variability of carbonate diagenesis in equatorial Pacific sediments deduced from radiogenic and stable Sr isotopes. Geochim. Cosmochim. Acta 148, 360-377.

Wheat, C.G., Fisher, A.T., 2008. Massive, low-temperature hydrothermal flow from a basaltic outcrop on 23 Ma seafloor of the Cocos Plate: chemical constraints and implications. Geochem. Geophys. Geosyst. 9. http://dx.doi.org/10.1029/ 2008 gc002136.

Winslow, C.G., Fisher, A.T., 2015. Sustainability and dynamics of outcrop-to-outcrop hydrothermal circulation. Nat. Commun. 6, 7567. http://dx.doi.org/10.1038/ ncomms8567.

Wheat, C.G., Mottl, M.J., Rudniki, M., 2002. Trace element and REE composition of a low-temperature ridge flank hydrothermal spring. Geochim. Cosmochim. Acta 66, 3693-3705. http://dx.doi.org/10.1016/S0016-7037(02)00894-3.

Wheat, C.G., Mottl, M.J., Fisher, A.T., Kadko, D., Davis, E.E., Baker, E., 2004. Heat flow through a basaltic outcrop on a sedimented young ridge flank. Geochem. Geophys. Geosyst. 5 (12). http://dx.doi.org/10.1029/2004GC000700.

Winterer, E.L., Sandwell, D.T., 1987. Evidence from En-Echelon cross-grain ridges for tensional cracks in the Pacific Plate. Nature 329, 534-537.

Ziebis, W., McManus, J., Ferdelman, T., Schmidt-Schierhorn, F., Bach, W., Muratli, J., Edwards, K.J., Villinger, H., 2012. Interstitial fluid chemistry of sediments underlying the North Atlantic gyre and the influence of subsurface fluid flow. Earth Planet. Sci. Lett. 323, 79-91. 